\title{
水面分光反射率比を用いた湖沼のクロロフィル $\mathrm{a}$ 濃度 及び濁度推定のための最適波長帯

\author{
THE OPTIMAL WAVELENGTH BAND FOR ESTIMATION OF CHLOROPHYLL-A \\ CONCENTIRATION AND TURBIDITY IN A LAKE USING WATER SURFACE SPECTRAL \\ REFLECTANCE RATIO
}

\author{
宮田佳明 ${ }^{1} \cdot$ 佐渡公明 ${ }^{2} \cdot$ Md.Monirul Islam ${ }^{3}$ \\ Yoshiaki Miyata,Kimiteru Sado and Md.Monirul Islam \\ 1 学生員 工修 北見工業大学 大学院工学研究科 (T090-8507 北海道北見市公園町 165) \\ 2フェロー 工博 北見工業大学教授 土木開発工学科（テ090-8507 北海道北見市公園町 165） \\ ${ }^{3}$ 正会員 博士（工学） 北見工業大学外国人研究者 土木開発工学科（T090-8507 北海道北見市公園町 165）
}

\begin{abstract}
The purpose of this research is finding out the optimal wavelength band for estimating inland water qualities with high precision using water surface spectral reflectance ratio for use in ocean color remote sensing. When the water surface spectral reflectance is observed in an inland water, it is generally recognized that an absorption band of light is in a red wavelength band $(660 \sim 680 \mathrm{~nm})$, and a fluorescence radiation band is in a longer wavelength band than red band. The proposed optimal wavelengths for the estimation of the inland water qualities are different among the observation points in the range of red and near infrared. This paper showed the difference of water surface reflectance ratio by two wavelengths of the absorption and the fluorescence radiation band has a correlation with chlorophyll-a concentration. The optimal wavelengths which are required for the estimation of chlorophyll-a concentration and turbidity were found out using correlation analysis.
\end{abstract}

Key Word: water surface reflectance ratio, optimal wavelength, chlorophyll- a concentration, Turbidity, water transparency, remote sensing

\section{1. はじめに}

石狩川水系の茨戸川は、昭和 8 年に石狩川本川から切 り離された、延長約 $20.2 \mathrm{~km}$ 、流域面積 $145.1 \mathrm{~km}^{2}$ 、湖容積 1,750 万 $\mathrm{m}^{3}$ の三日月湖である。ボート・釣りに利用され るなど、地域住民の憩いの場となっているほか、全域が 漁業利用されているが、都市域からの生活排水などの影 響により、水質目標を超過している状況である。また、 平成 6 年 8 月 29 日にアオコの発生が見られており、毎年 $100 \mu \mathrm{g} / \mathrm{L}$ を超える高濃度のクロロフィル a が観測されて いる。このような水域のアオコ発生対策を効果的に行う ためには、植物プランクトンの葉緑素であるクロロフィ ル a 濃度の現状を湖沼全体で把握する必要があり、広域 ふ心短時間に测定じさるリ七ートセンシング技術が有効 と考えられる。

ところで、水面分光反射率比を用いた外洋水のクロロ フィル a 濃度推定は多くの研究がされており、490、555nm の水面分光反射率比を用いる OC2-V2 アルゴリズムや 443 、 490、510nm の内の最大值と $555 \mathrm{~nm}$ の水面分光反射率比を 用いる OC4-V4 アルゴリズムが用いられてきた ${ }^{1), 2) 。(か ~}$
し、上記の水面分光反射率比を内陸水に適用すると、内 陸水は陸域由来の濁質の影響を受けやすいので、クロロ フィル a 濃度推定の精度が悪い ${ }^{2)}$ 。 網走湖、霞ヶ浦、塘 路湖における水面分光反射率の観測結果によると、赤の 波長帯（660～680nm）に光の吸収帯があり、それよりも 長波長側に蛍光放射帯を有する特性が認められる ${ }^{2)}$ 3),4),5)。また、最適波長帯は、赤〜近赤外の範囲で観測地 点によって、多少ずれを生じている。以上のように、リ モートセンシングを用いた内陸水のクロロフィル a 濃度 推定のために用いる最適波長帯を明らかにする必要があ る。

本研究は、茨戸川全域及びその周辺水域の水面分光反 射率、クロロフィル a 濃度、濁度を測定し、それぞれの 観測項目についての特性を把握した。次にクロロフィル $\mathrm{a}$ については、 2 波長を用いた水面分光反射率比とクロロ フィル a 濃度の相関係数を算出し、濁度については、1 波長における水面分光反射率と濁度、及び 2 波長を用い た水面分光反射率比と濁度の相関係数をそれぞれ算出し た。算出した相関係数に基づき、クロロフィル $\mathrm{a}$ 濃度及 び濁度推定に最適となる波長、波長帯幅、平均濃度水深 
（深さ方向の平均濃度を求める範囲の水深）を選定した。

\section{2. 現地観測}

\section{（1）現地観測概要}

茨戸川での現地観測は、2004 年 8 月 10 日〜2004 年 8 月 11 日までの 2 日間において、図-1に示したとおり、茨 戸川の上部湖盆、中部湖盆、下部湖盆の 26 地点で 38 回 実施した。観測内容は、(株)オプトリサーチ製の多目的 分光放射計(MSR-7000) を用いて分光放射輝度 (本研究で は 350〜900nm の波長範囲を使った)、(株)アレック電子 製のクロロテック (ACL1180-DK)を使って、湖水のクロロ フィル a 濃度及び蜀度を測定した。また、セッキー円板 を用いて透明度を測定した。図-2に現地観測内容を示す。

2004 年 8 月 10 日の天候は晴れ一時量りで雲量は $1 \sim 8$ 、 気温は $24.5 \sim 30.6^{\circ} \mathrm{C}$ であった。2004 年 8 月 11 日の天候

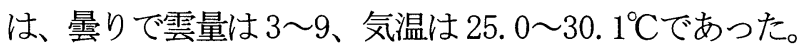

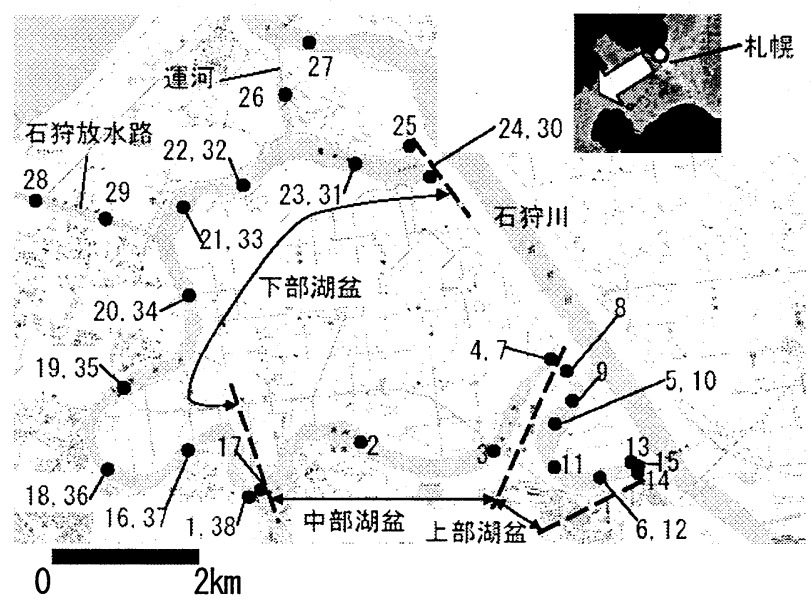

図-1 茨戸川（上部湖盆〜下部湖盆）及び周辺水域の 観測 NO. 一覧

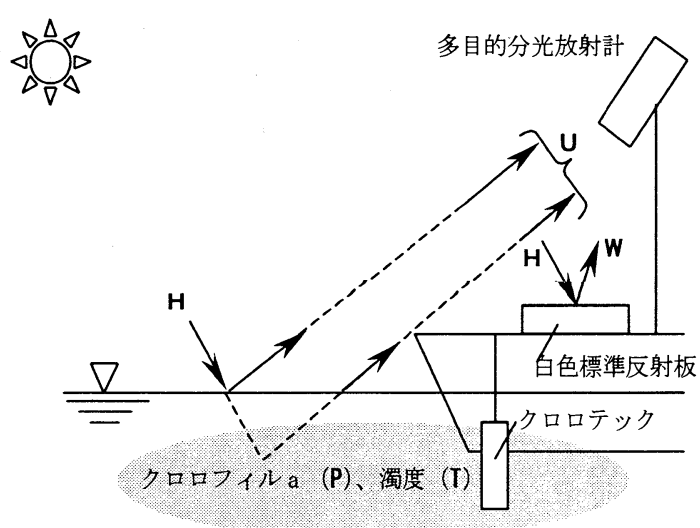

$\boldsymbol{H}(=\pi \mathbf{W})$ : 水面下向き分光放射照度 $\left(\mathrm{Wm}^{-2} \cdot \mu \mathrm{m}^{-1}\right)$

$\mathbf{W}$ : 白色標準反射板の分光放射輝度 $\left(\mathrm{Wm}^{-2} \cdot \mu \mathrm{m}^{-1} \cdot \mathrm{sr}^{-1}\right)$

$\mathrm{U}:$ 水面直上の水面上向き分光放射輝度 $\left(\mathrm{Wm}^{-2} \cdot \mu \mathrm{m}^{-1} \cdot \mathrm{sr}^{-1}\right)$

$\mathbf{P}:$ クロロフィル $\mathrm{a}$ 濃度 $\left(\mu \mathrm{g} \cdot \mathrm{L}^{-1}\right) 、 \mathbf{T}:$ 濁度 $(\mathrm{ppm})$

図-2＼cjkstart現地観測内容

\section{（2）水面分光反射率の測定方法}

図-2で示されているように、多目的分光放射計により、 白色標準反射板を用いて太陽光の分光放射輝度 $W$ を測定 し、次に水面に対して水面直上の水面上向き分光放射輝 度Uを測定した後、次式により水面分光反射率を算出す る。なお、 1 回の測定時間は約 1 分と短いので、UとWの 2 回測定中の太陽からの日射量は一定と仮定し、白色標準 反射板に影が入った場合は再計測しなければならない。

$$
R_{s}=\frac{U}{W}
$$

ここに、 $R_{s}$ : 水面分光反射率， $U$ : 水面直上の水面上向 き分光放射輝度 $\left(\mathrm{Wm}^{-2} \mu \mathrm{m}^{-1} \mathrm{sr}^{-1}\right), W$ : 白色標準反射 板の分光放射輝度 $\left(\mathrm{Wm}^{-2} \mu \mathrm{m}^{-1} \mathrm{sr}^{-1}\right)$ である。

\section{（3）クロロフィル a濃度、濁度の測定方法}

各地点において、クロロテックのセンサーを鉛直方向 に $0.1 \mathrm{~m}$ ピッチで水面から湖底まで下降させて、クロロフ イル a 濃度 (ウラニン基準のクロロフィル a 濃度)、濁度 を測定した。

\section{3. 現地観測結果}

\section{(1) 水面分光反射率}

現地観測で得られた水面分光反射率に基づき、図-3に 水面分光反射率の波長ごとのスペクトルを示す。なお、 水面分光反射率は、太陽高度の影響により変化するため 6), 7), 8)、太陽高度 $\theta$ の值も記入した。図中の平均クロロフ イル a 濃度及び平均濁度は、各観測地点における水面か ら透明度水深までのクロロフィル a 濃度及び濁度の平均 值である。この平均濁度の最大值(最大值を示す地点)、 平均値 (平均値に最も近い地点)、最小值(最小值を示寸地 点) はそれぞれ 48ppm (No. 15)，16ppm (No. 2), 9ppm (No. 19) であり図中に記載している。最大值 48ppm を持つ地点の 水面分光反射率は、16,9ppm の地点より大きく、また 16 と 9ppm の地点については、450nm 以下の波長を除いて、 16ppm の地点の方が概ね大きくなっている。太陽高度によ る影響があるものの濁度上昇に応じて水面分光反射率が 増加する傾向が南る上考光られる ${ }^{9)}$

植物プランクトンに含まれるクロロフィル a について は、一般に、赤 $(660 \sim 680 \mathrm{~nm}) 、$ 青 $(480 \sim 500 \mathrm{~nm})$ の光が 吸収され、緑 $(550 \mathrm{~nm}$ 付近) と近赤外 $(700 \mathrm{~nm}$ 付近) が蛍 光放射帯である。外洋水においては、陸域由来の無機䀣 濁物質や溶存有機物が少なく、植物プランクトンの割合 が高いため、青と緑の波長をクロロフィル a 濃度の推定 に用いることが多い ${ }^{1), 2)}$ 。一方、内陸水では、著者ら ${ }^{2)}$ が網走湖で、沖ら ${ }^{3)}$ が霞ケ浦で、加藤ら ${ }^{4}$ が塘路湖で行っ た水面分光反射率の測定結果によると、光合成を行うた めの吸収帯（赤：660～680nm） と余分な光を放射する蛍 
光放射帯（690～710nm）が明瞭に示される結果となって いる。今回の茨戸川の測定結果（図-3）でも同様の傾向 が認められ、吸収帯と蛍光放射帯の差はクロロフィルa 濃度に比例して拡大寸る傾向を示している。

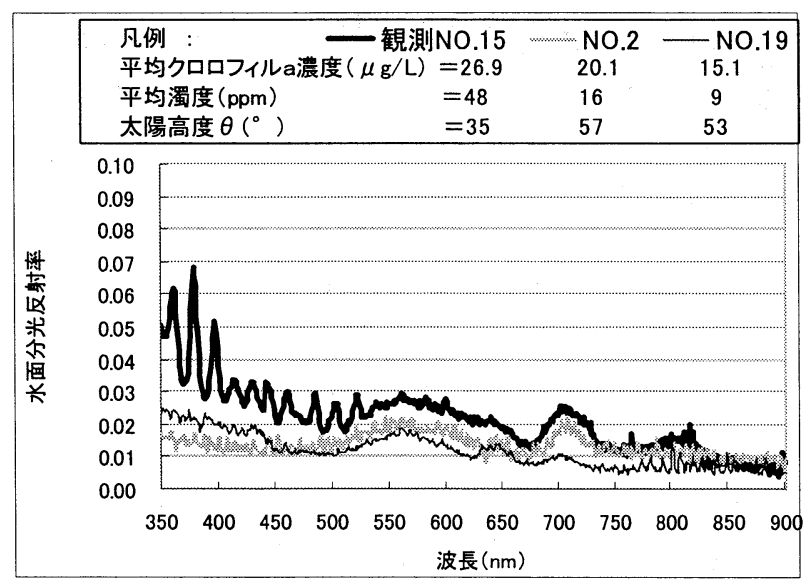

図-3 水面分光反射率のスペクトルと平均濁度、 平均クロロフィル $\mathrm{a}$ 濃度

\section{（2）濁度及び透明度、水温}

図-4は、各地点における透明度水深までの平均濁度を 示しており、1 地点に対して 2 回観測を行っている場合は、 2 回の平均值を表示した。上部湖盆の濁度は、中部、下部 湖盆と比べて高い数值を示し、特に上部湖盆最上流端で 48ppm と最大值を示している。中部、下部湖盆と下流にい くにつれて值が低下し、下部湖盆の NO. 19\&NO. 35 の地点 では、最低の 10ppm まで低下する。N0.1\&NO. 38〜 N0.22 \&NO. 32 の区間は、伏古川流入による希釈により、茨戸川 の濁度が低下していると考えられる。透明度については、 濁度と負の相関で推移しており、濁度が最も高い上部湖 盆の NO. 15 で $0.25 \mathrm{~m}$ と最小になっている。なお、NO.27 を除いて、透明度水深が観測地点の水深と以上の観測 NO. はなく、底面による影響は小さいと考えられる。

図-5 の濁度の鉛直分布は、全観測地点において、最大、 最小、平均的な值を図示したものである。最小值と平均 的な值については、ほぼ、鉛直方向に一定の值を示して

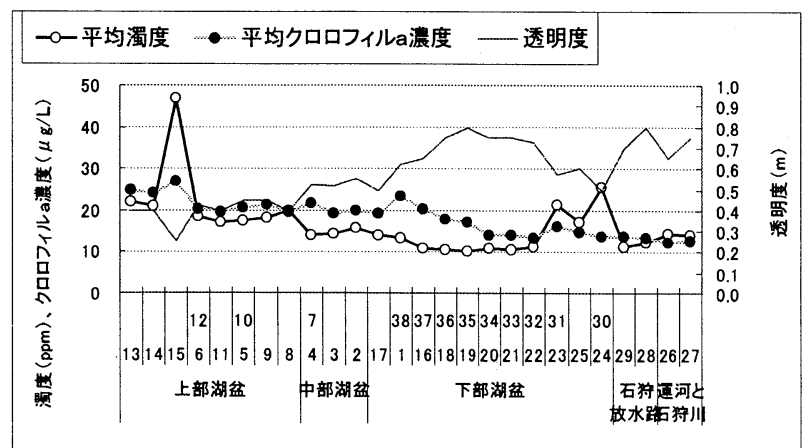

図-4 平均濁度、透明度及び平均クロロフィル $\mathrm{a}$ 濃度の測定 結果（数字は観測 NO.）

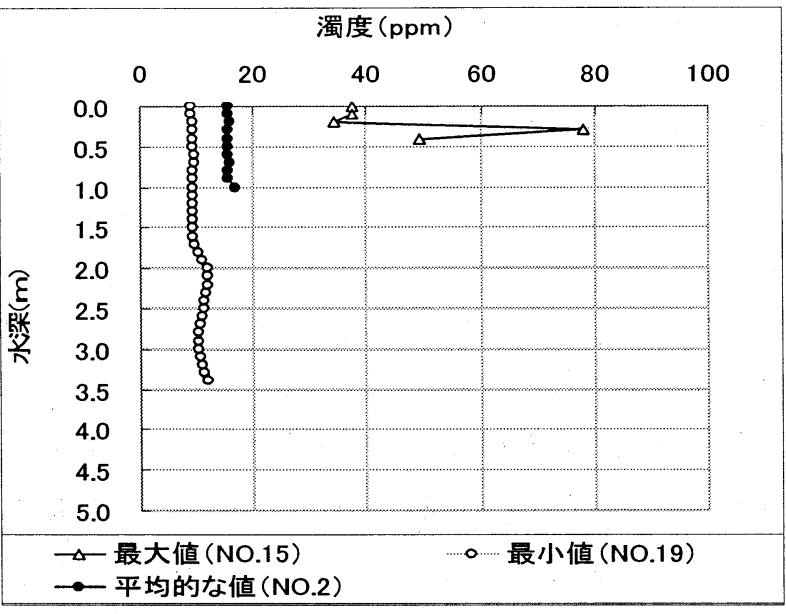

図-5 濁度の鉛直分布

いるが、水深の浅い上部湖盆 N0.15 においては下層で 70ppm を超えており、流入水による希釈効果が乏しく、風 波や観測時の擾乱による巻上げの影響が大きいと考えら れる。

\section{（3）クロロフィルa濃度}

透明度水深までの平均クロロフィル $\mathrm{a}$ 濃度の地点変化 については、図-4 中に示した。濁度と同様に上部、中部、 下部湖盆の順に濃度が低下しており、上部湖盆の N0. 15 で最大值の $27 \mu \mathrm{g} / \mathrm{L}$ を示すが、中部、下部湖盆と下流に いくにつれて值が低下し、下部湖盆のN0.22\&N0.32では、 最低の $13 \mu \mathrm{g} / \mathrm{L}$ まで低下している。なお、石狩放水路で は曝気を実施し、運河では、伏古川からの流入水により、 流動が生じているため、植物プランクトンの発生が抑制 されて、低濃度となっていると考えられる。

図-5 と同様にクロロフィル a 濃度の鉛直分布を図-6に 図示する。特に明確な鉛直分布は認められず、水表面と 同程度の濃度となっている。全観測地点の中で、水温と 塩分濃度の水深方向の最大変動幅はそれぞれ、No.7 の $24.2 \sim 27.6^{\circ} \mathrm{C}$, No. 29 の0.7 1. OPSU と少なく、密度の鉛 直分布についてもほぼ一様と考えられる。

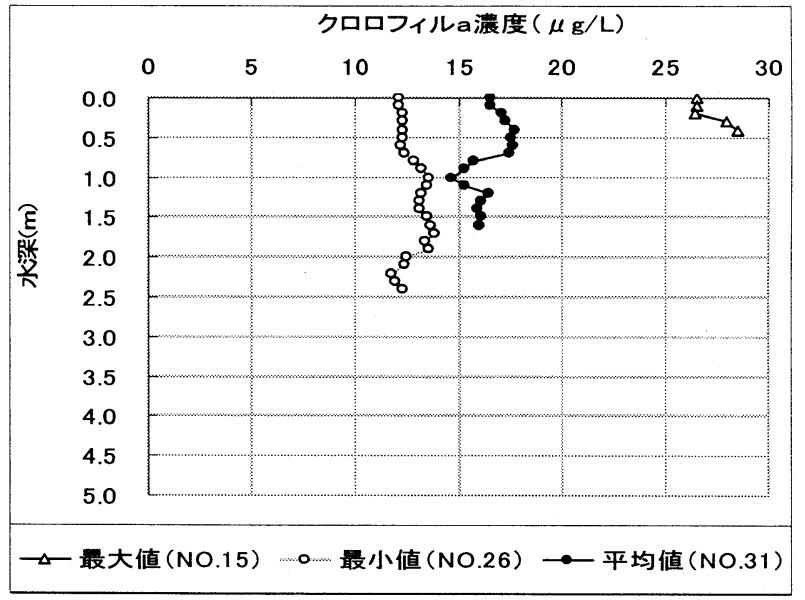

図-6 クロロフィル a 濃度の鉛直分布 


\section{4. 相関係数による最適波長選定}

\section{（1）相関係数算出ヶース}

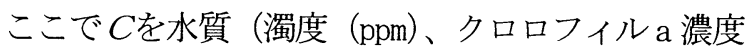
$(\mu \mathrm{g} / \mathrm{L}))$ として、水面分光反射率を用いた水質濃度推 定式を（2）式に示す。 $\bar{C}$ は、水深 $n h(\mathrm{~h}$ : 透明度水深 (m), $\mathrm{n}$ : 透明度水深の $\mathrm{n}$ 倍を表わ寸定数) に対する平均 水質である。式（3）のRは、波長範囲 $\lambda_{1}-\delta \sim \lambda_{1}+\delta$ の 平均水面反射率 $\bar{R}_{s}\left(\lambda_{1} \pm \delta\right)$ と波長範囲 $\lambda_{2}-\delta \sim \lambda_{2}+\delta$ の 平均水面反射率 $\overline{R_{s}}\left(\lambda_{2} \pm \delta\right)$ との水面反射率比の常用対数 である。a1, a2 は定数である。 $\log \bar{C}$ と $R$ との最も良い 相関を正とするために (3) 式の右辺に負号を付ける。現 地観測における全観測地点の結果を回帰分析し、その回 帰直線式、相関係数 $\mathrm{r}$ を算出した。また、算出した相関 倸数 $\mathrm{r}$ が最大值となる $\lambda_{1} 、 \lambda_{2}$ の中心波長 $(\mathrm{nm})$ 、波長帯 幅 $\delta(\mathrm{nm})$ 及び $n$ を求めた。なお、 $\lambda_{1}$ 及び $\lambda_{2}$ は、350〜 $900 \mathrm{~nm}$ の範囲を $1 \mathrm{~nm}$ 刻み、 $\delta$ は $0 \sim 10 \mathrm{~nm}$ の範囲を $1 \mathrm{~nm}$ 刻み、 $n$ は $0.5 \sim 2.0$ の範囲を 0.5 刻みとして全ての組み合わせ について相関係数 $\mathrm{r}$ を算出した。

$$
\begin{aligned}
& \bar{C}(n h)=10^{a 1 \times \mathrm{R}+a 2} \\
& R=-\log \frac{\overline{R s}\left(\lambda_{1 \pm \delta)}\right.}{\overline{R s}\left(\lambda_{2 \pm} \delta\right)}
\end{aligned}
$$

または、

$$
R=\log \overline{R_{S}}\left(\lambda_{1 \pm} \delta\right)
$$

クロロフィル $\mathrm{a}$ の場合は、前述の通り、光の吸収と蛍 光放射の特性を持つことから、Rについては、（3）式の みについて計算し、濁度の場合のRについては、(3) 式 及び（4）式について計算を行った。下表に相関係数算出

\begin{tabular}{|c|c|c|}
\hline 水質項目 & $\begin{array}{l}\text { 水面分光反射率 } \\
\text { による } R((4) \text { 式 }\end{array}$ & $\begin{array}{l}\text { 水面分光反射率比 } \\
\text { による } R(\text { (3) 式) }\end{array}$ \\
\hline 加口价 a 濃度 & - & ケース 1 \\
\hline 濁度 & ケース 2 & ケース 3 \\
\hline
\end{tabular}
ケースを示し、以下に結果を示す。

\section{表-1 相関係数算出ケース}

\section{（2）クロロフィルa濃度}

\section{a) ケース 1}

波長帯幅 $\delta=0 \mathrm{~nm}$ 、クロロフィル $\mathrm{a}$ 濃度の平均值を求め る水深を透明度水深まで $(n=1)$ とし、光合成のための 光の吸収帯及び蛍光放射帯の中心波長 $\lambda_{1}, \lambda_{2}$ に対する相 関係数 $\mathrm{r}$ の変化を図-7 (a) 〜 (c) に示す。これらの図は最 適中心波長を求めるにあたり、 $\lambda_{1}$ を横軸にとりパラメー タ $\lambda_{2}$ の間隔 $\Delta \lambda_{2}$ を 100, 20, 1 2nm と段々小さくしてい く探索課程を示している。図-7 (a) を見ると、外洋水のク

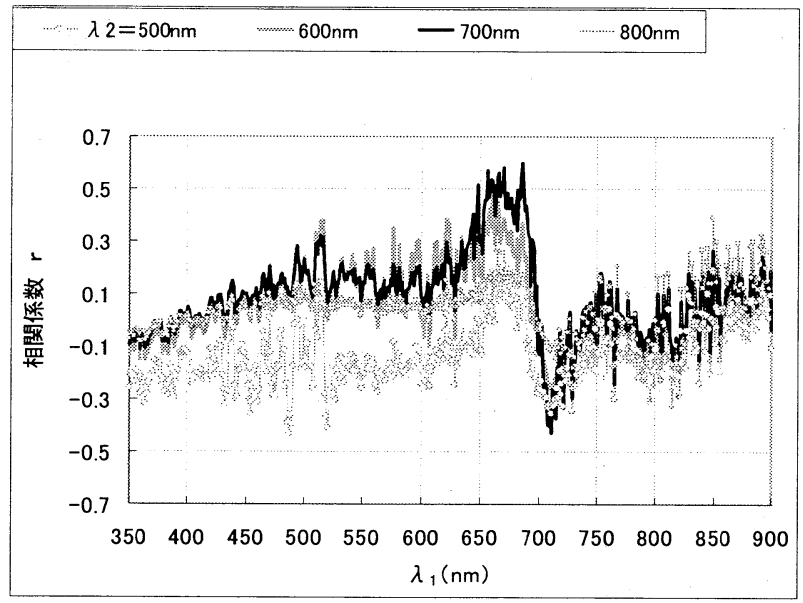

(a) $\lambda_{2}=500 \sim 800 \mathrm{~nm}\left(\Delta \lambda_{2}=100 \mathrm{~nm}\right)$

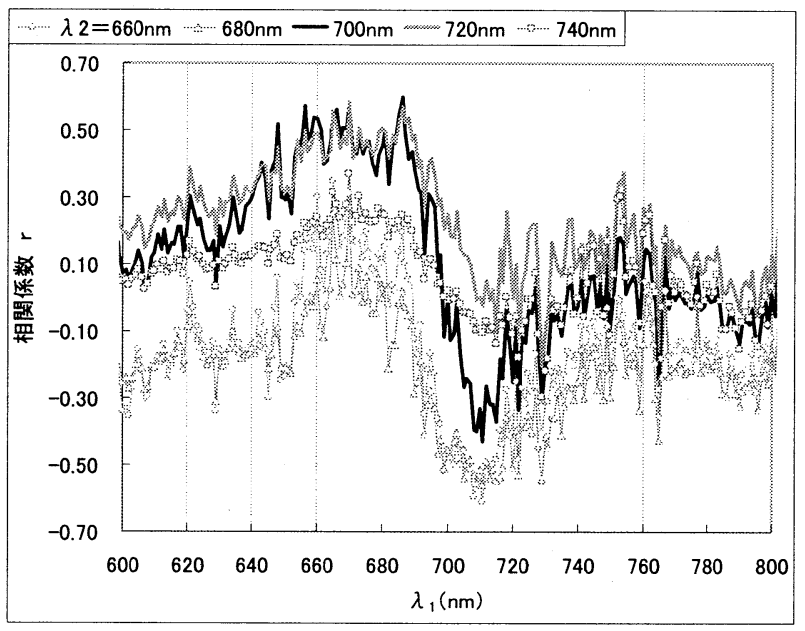

(b) $\lambda_{2}=660 \sim 740 \mathrm{~nm}\left(\Delta \lambda_{2}=20 \mathrm{~nm}\right)$

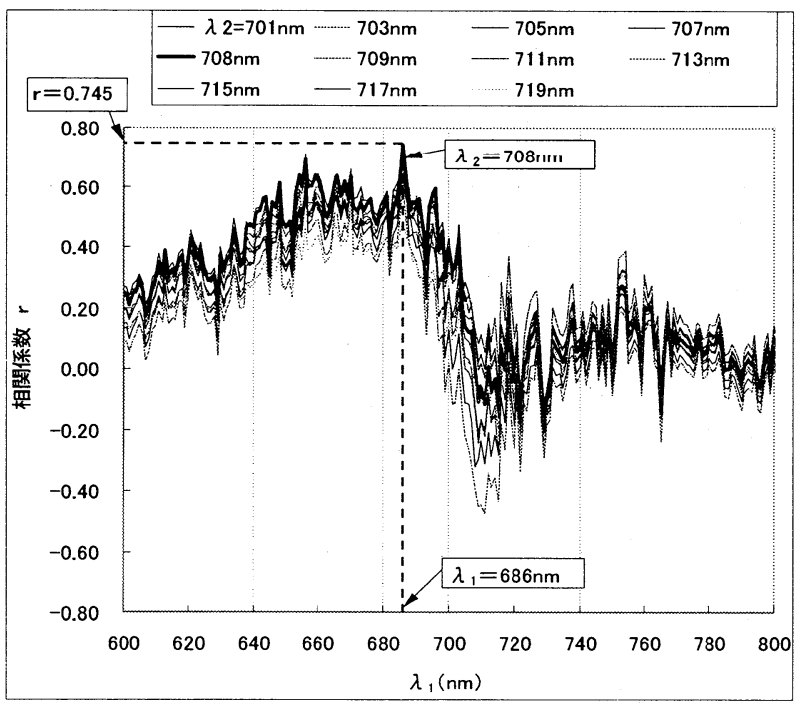

(c) $\lambda_{2}=701 \sim 719 \mathrm{~nm}\left(\Delta \lambda_{2}=1,2 \mathrm{~nm}\right)$

図-7 クロロフィル $\mathrm{a}$ 濃度推定のための最適中心波長 （ $\delta=0 \mathrm{~nm} 、 \mathrm{n}=1$ の場合）

ロロフィル a 濃度推定に用いられる $\lambda_{1}=440 \sim 510 \mathrm{~nm}$ 及 び $\lambda_{2}=500 \sim 600 \mathrm{~nm}$ の波長において、相関係数の絶対值 
が 0.5 以下と低くなっており、内陸水である茨戸川のク ロロフィル a 推定には、上記波長帯が適さないことを示 している。図-7 (a) では、 $\lambda_{1}$ が 650 690nm、 $\lambda_{2}$ が 700nm の場合にピークを示しており、図-7(b)において $\lambda_{2}$ の $700 \mathrm{~nm}$ を中心し、20nm 毎にプロットしたところ、 $\lambda_{1}$ が $655 \sim 690 \mathrm{~nm} 、 \lambda_{2}$ が $700 \mathrm{~nm}$ 及び $720 \mathrm{~nm}$ において相関係数 $\mathrm{r}$ が 0.57 以上の最大值を示した。さらに、 $\lambda_{2}$ を $700 \sim 720 \mathrm{~nm}$ の範囲で 1〜2nm 毎に確認したところ、図-7 (c)に示した とおり、 $\lambda_{1}$ が $686 \mathrm{~nm} 、 \lambda_{2}$ が 708nm の場合に 0.745 の相関 係数の最大值が得られた。また、吸収帯が近赤外域 $\left(\lambda_{1}\right.$ $>700 \mathrm{~nm})$ に入ると相関係数が急に低下寸ることが示され ている。

次に、平均クロロフィル a 濃度を求める水深及び波長 帯幅 $\delta$ と相関係数 $\mathrm{r}$ との関係を図-8 に示寸。この図は各 $\delta, \mathrm{n}$ 值に対し最適中心波長を用いたときの相関係数を

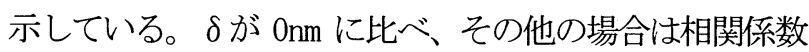
の低下寸る傾向が見られる。 $\delta$ が $0 \mathrm{~nm}$ で、 $n=1.0$ の場合 について、最大の相関係数 0.745 となっている。結局ク ロロフィルa濃度推定には $\lambda_{1}=686 \mathrm{~nm}, \quad \lambda_{2}=708 \mathrm{~nm}, \quad \delta=0 \mathrm{~nm}$, $r=1.0$ の場合が最適である。この最適条件のときの式(2) によるクロロフィル a 濃度推定值と実測值との比較の図 は紙数の関係で省略するが、両者の相関係数は 0.697 と得られた。

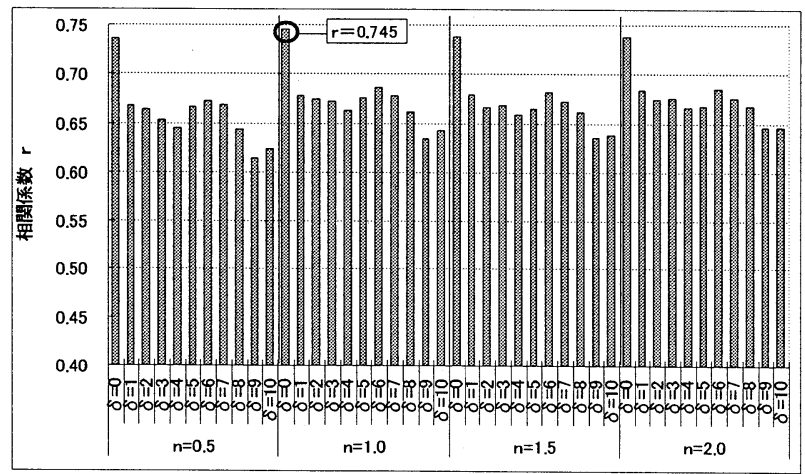

図-8 クロロフィル $\mathrm{a}$ 濃度推定のための最適な $\delta(\mathrm{nm})$ 值、 $n$ 值 $\left(\lambda_{1}, \lambda_{2}\right.$ は最適中心波長)

\section{（3）濁度}

a) ケース 2

$n=0.5$ の場合について、波長 $\lambda_{1 、}$ 波長帯幅 $\delta$ と相関係

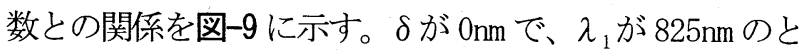
き、相関係数は最大值 0.429 を示し、相関が悪い。また、 $n \neq 0.5$ の場合は、相関係数が 0.429 以下の值を示した。 従って、水面分光反射率を用いた（4）式による濁度推定 は不適切と考えられる。

\section{b) ケース 3}

$\delta=0 \mathrm{~nm} 、 n=0.5$ の場合、図-10(a) では、 $\lambda_{2}=600 \mathrm{~nm}, \lambda_{1}=$ $511 \mathrm{~nm}$ でピークを示した。図-10(b)において $\lambda_{2}$ の 560〜 $640 \mathrm{~nm}$ について、20nm 毎にプロットしたところ、 $\lambda_{1}=511 \mathrm{~nm} 、$ $\lambda_{2}=600 \mathrm{~nm}$ において、相関係数がピークを示した。さらに、

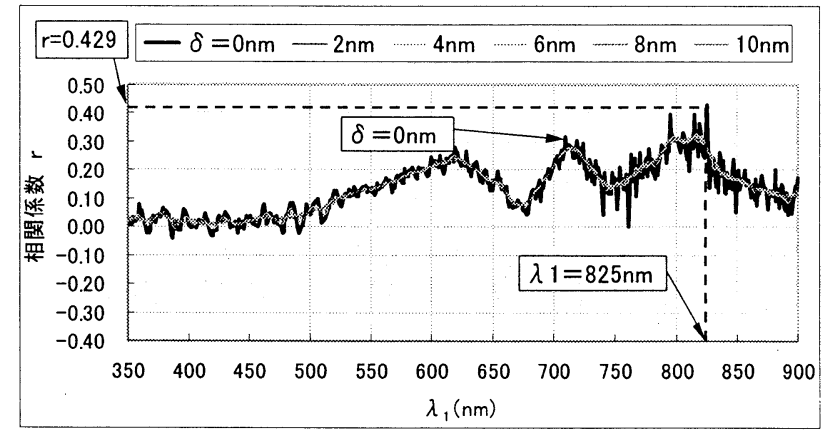

図-9 分光反射率を用いた濁度推定のための最適な $\lambda_{1}, \delta$ ( $\mathrm{n}=0.5$ の場合)

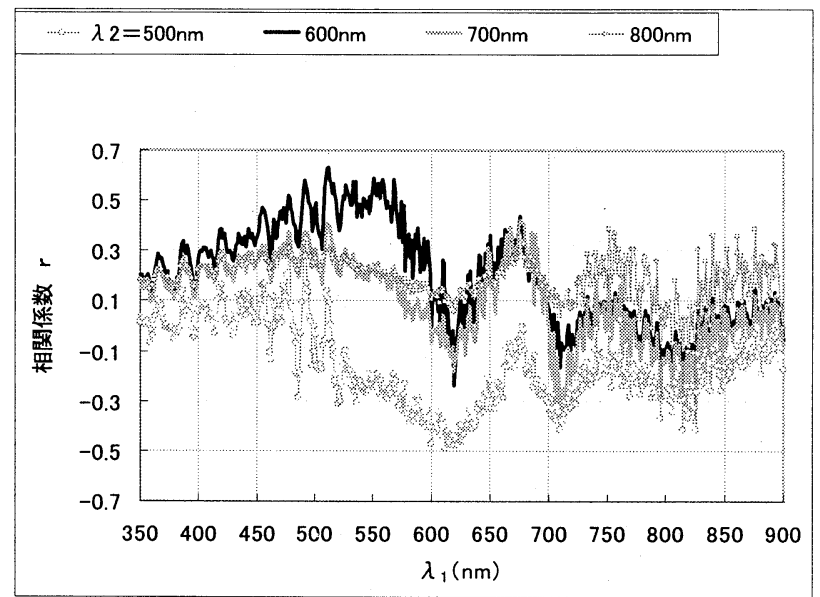

(a) $\lambda_{2}=500 \sim 800 \mathrm{~nm}\left(\Delta \lambda_{2}=100 \mathrm{~nm}\right)$

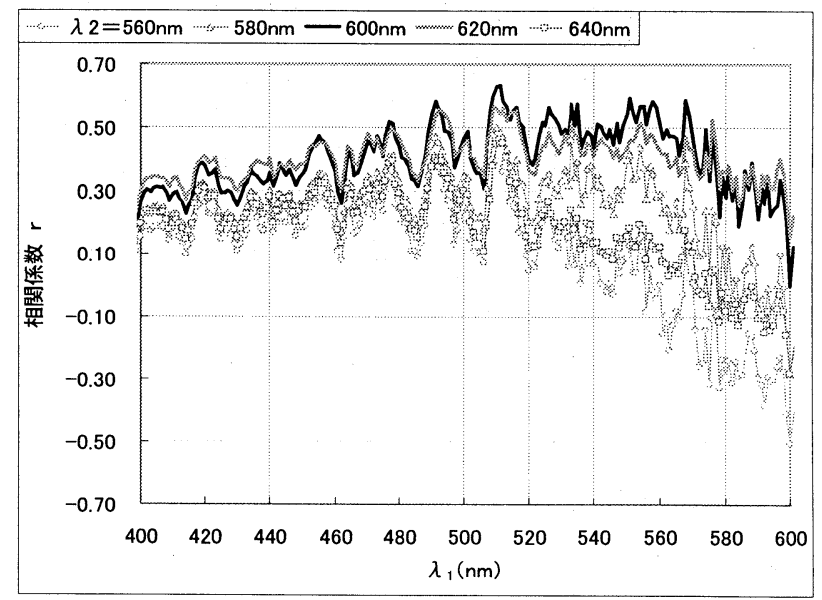

(b) $\lambda_{2}=720 \sim 800 \mathrm{~nm}\left(\Delta \lambda_{2}=20 \mathrm{~nm}\right)$

図-10 濁度推定のための最適中心波長（その 1$)$ （ $\delta=0 \mathrm{~nm} 、 n=0.5$ の場合）

図-10(c)に示したように、 $\lambda_{2}$ を 601〜619nm の範囲で 1 ～2nm 毎に確認すると、図に示すとおり、 $\lambda_{1}$ が $510 \mathrm{~nm}$ 、 $\lambda_{2}$ が $612 \mathrm{~nm}$ の場合に相関係数の最大值 0.668 が得られた。 次に、 $\lambda_{1}, \lambda_{2}$ を各 $\delta, \mathrm{n}$ に対する最適值に選定した場 合について、 $\mathrm{n}$ 及び $\delta$ と相関係数との関係を図-11に示寸。 $\delta=0 \mathrm{~nm}, n=0.5$ の場合に相関係数が最大の 0.668 となっ ている。従って、濁度推定は、水面分光反射率比 (3) 式 を用いて $\lambda_{1}=510 \mathrm{~nm} 、 \lambda_{2}=612 \mathrm{~nm} 、 \delta=0 \mathrm{~nm} 、 n=0.5$ の場合 が最適と考えられる。この最適条件のとき式(2)による濁 度の推定值と実測值との相関係数は 0.550 と得られた。 


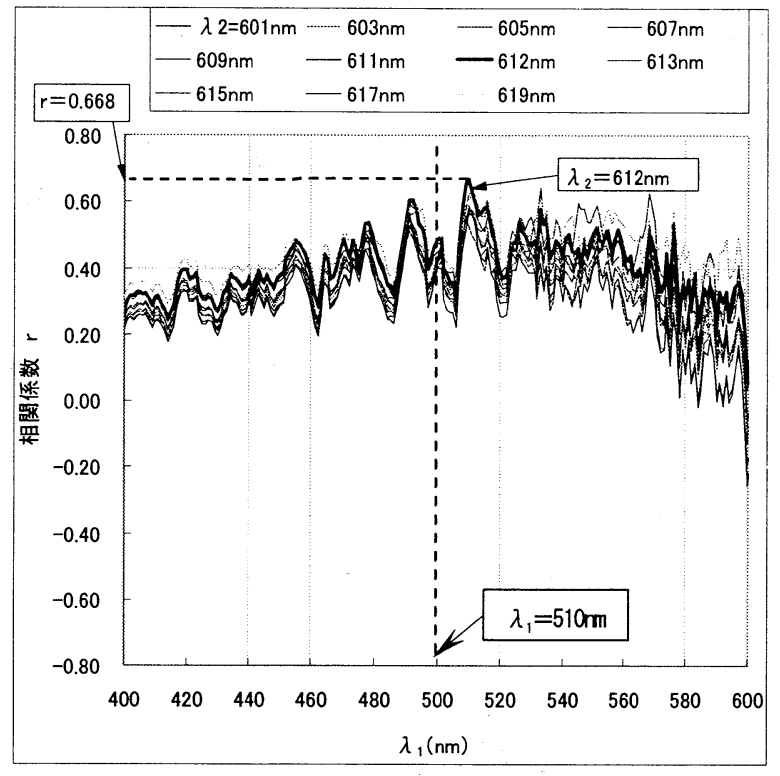

(c) $\lambda_{2}=781 \sim 799 \mathrm{~nm}\left(\Delta \lambda_{2}=1,2 \mathrm{~nm}\right)$

図-10 濁度推定のための最適中心波長（その2）

（ $\delta=0 \mathrm{~nm} 、 n=0.5$ の場合）

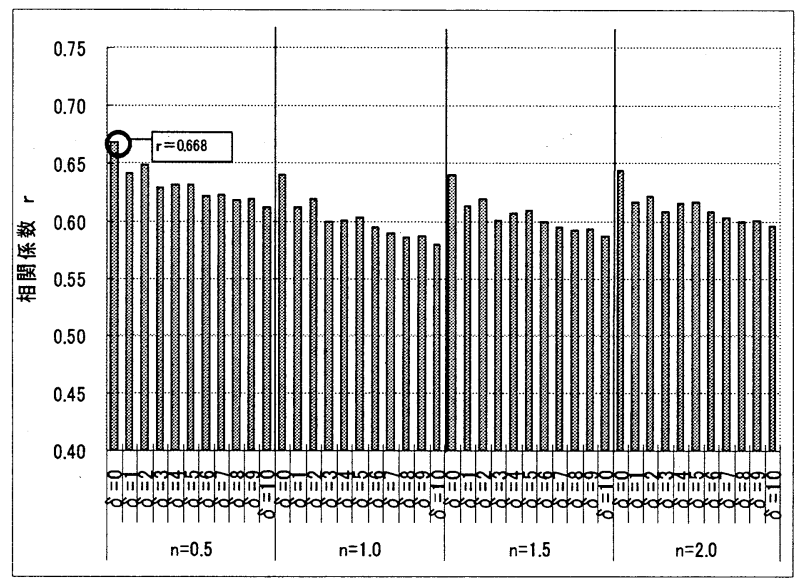

図-11 濁度推定のための最適な $\delta(\mathrm{nm})$ 值、 $n$ 值 $\left(\lambda_{1}, \lambda_{2}\right.$ は最適中心波長)

\section{5. おわりに}

以上、水面分光反射率比を用いた湖沼のクロロフィル $\mathrm{a}$ 濃度及び濁度の推定に関して、以下の知見が得られた。

（1）茨戸川の現地観測で得られた水面分光反射率のスペ クトルをみると、網走湖で著者らが測定したスペク トルと同様に光合成を行うための吸収帯（赤 : 660 ～690nm） と余分な光を放射する蛍光放射帯（690～ $710 \mathrm{~nm})$ が明瞭に認められる。

（2）水面分光反射率比を用いるときのクロロフィル a 濃 度推定の最適波長は、吸収帯で $686 \pm 0 \mathrm{~nm}$ の可視域、 蛍光放射帯で 708 0 nm の近赤外域である。

（3）水面分光反射率と濁度との相関は、水面分光反射率 比と濁度との相関に比へ、非常に悪い。

（4）水面分光反射率比を用いるときの濁度推定のための 最適な波長帯は、 $510 \pm 0 \mathrm{~nm} 、 612 \pm 0 \mathrm{~nm}$ である。
（5）水深方向の平均值については、クロロフィル $\mathrm{a}$ 濃度 では、透明度水深までの範用 $(n=1)$ 、濁度では透明 度水深の $1 / 2$ の水深範囲 $(n=0.5)$ 、で求めるのが最 適と得られた。

植物プランクトンの種類や濁質成分が異なれば、光の 吸収・散乱特性が異なり最適波長にも影響する。従って 本論文で夏季の茨戸川に対し得られた結論が、一般的な 結果となるか否かを判定するには、今後多くの湖沼・貯 水池における幅広い濃度範囲の観測デー夕を検討しなけ ればならない。

本研究では、水面分光反射率比と水質濃度との相関を $1 \mathrm{~nm}$ ごとに評価することで最適な波長帯を把握できた。 クロロフィル a 濃度のための最適中心波長の差は $22 \mathrm{~nm}$ しか離れていない。現在は $20 \mathrm{~nm}$ の波長帯を持つ海色リ モートセンシングセンサーが主流であるが、今後は分解 能 $1 \mathrm{~nm}$ のハイパースペクトル衛星データを利用寸るに あたり、本研究の成果が活用できると考える。

謝辞 : 本研究は文部科学省の科研費 $(14 \cdot 02334)$ の助成を 受けた。また、茨戸川現地調査では、北海道開発局石狩 川開発建設部札幌河川事務所、北開水エコンサルタント の多大なるご協力を頂き、ここに感謝の意を表します。

\section{参考文献}

1）岸野元彰、福島 甫、虎谷充浩、陳 文忠、田中昭彦: 海 洋リモートセンシング,第 3 回海色リモートセンシング, 日本 リモートセンシング学会誌, Vol.22 No.3, pp.336-354, 2002.

2）丹田善和、佐渡公明、Md. Monirul Islam、中尾隆志 : 水面 分光反射率を用いた網走湖のクロロフィル $\mathrm{a}$ 濃度推定, 平成 15 年度土木学会北海道支部論文報告集, 第 60 号, pp.468471, 2004

3）洲一雄、安岡善文: 高濃度水域における近赤外波長带を含 む二波長によるクロロフィルa 推定モデルの作成，日本リモ ートセンシング学会誌, Vol.16 No.4, pp.1-9, 1996.

4）加藤晃司、渋谷直生、中津川誠、新庄 興: リモートセンシ ングによる釧路 3 湖沼の富栄養化状態の把握, 水文水資源学 会 2004 年研究発表会要旨集, pp.142-143, 2004.

5）佐渡公明 : 衛星画像を用いた湖沼のアオコおよび水温モニタ リングシステムの開発, 平成 $12 \sim 13$ 年度科学研究費補助金 (基礎研究(B)(2)）研究成果報告書, pp.11-20, 2002.

6) 近藤純正 : 水環境の気象学,朝倉書店, pp.161-163, 1996.

7）新井 正 : 水温論, 共立出版, pp. $28-45,1974$.

8) Tennessee Valley Authority: Heat and Mass Transfer between a water surface and the atmosphere, Water Resources Research Laboratory Report No.14, pp2.1-2.36, 1972.

9）日本リモートセンシング研究会 : 図解リモートセンシング, 日本測量協会, pp.18-21,1998.

（2004.9. 30 受付） 